\title{
Law and Political Economy of Water User Associations
}

Arkaja Singh

Paper prepared for the workshop entitled 'Water, Law and the Commons' organised in Delhi from 8 to 10 December 2006 by the International Environmental Law Research Centre (IELRC) in the context of the research partnership 2006-2009 on water law sponsored by the Swiss National Science Foundation (SNF) 


\section{Law and Political Economy of Water User Associations}

\subsection{Introduction}

Water users associations are user groups formed to manage irrigation infrastructure and water resources. In development literature and practice, such user groups are often the response for state failure to perform a whole range of public functions. User groups have been formed for the management and supervision of state-run schools, local water supply, sanitation, collection and disposal of solid waste and of course for the operation and maintenance of local irrigation systems. The apparent logic of these user groups seems to be that as direct beneficiaries of the service, they have a strong incentive to ensure that the service is managed well. Internally these user groups are organised quite differently from state delivery systems - instead of having formal structures of accountability and hierarchy, they supposed to be run like community groups, with an implicit assumption that social relations between members of the community will deter office bearers from high jacking the user group and misappropriating its assets.

The level of responsibility that water user associations take on varies. They may be at least partly responsible for service delivery, or they may have supervisory powers over public officials who actual run the system. In other cases they may simply be collectives of consumer-citizens, somewhat akin to a consumer action group. In different countries and states, water user associations also have varying levels of control over, as well as responsibility for the irrigation infrastructure and water resources they manage. They may be completely voluntary associations, sometimes drawing reference from local custom, but with no formal handover of responsibility and management control from formal state institutions. Others, like the water user associations of Orissa are formal state institutions, almost like a limited form of local government.

My paper looks at what Orissa's Pani Panchayat law does, in terms of transfer of property rights and the position of the state vis-à-vis its water user associations after the law came into effect. The paper will look at whether, and to what extent the Pani Panchayat law brings about a privatisation of water through the divestment of rights and responsibilities. Yet the "law" of Pani Panchayats is mainly an administrative reform of fairly recent origin, and it is in fact part of a cluster of similar reforms that have been implemented in many Indian states and elsewhere in the world with the support of multilateral organisations. Looking at the immediate policy context provides some insight into the administrative decision-making process behind the law, but finally it is more important to look to the local political economy to understand the motivations and possible impacts of the law/ reform in the local context.

\subsection{What does the Pani Panchayat Law do?}

Water user associations reflect a shift away from the command model of government, preferred by bureaucrats in the colonial period and further 
strengthened by Indian state governments in the period after Independence. When government irrigation departments took over management and control of irrigation infrastructure, the state took full responsibility for investment in irrigation systems and it also assumed full control over management and decision-making. This management structure prevailed during the Green Revolution period in both Green Revolution states as well as in other less successful states, which suggests that the model itself is neither programmed for government failure nor necessarily success. However, cases of corruption and failure in state irrigation departments often become the popular context for reform and the setting up of water user associations.

In neo-liberal analyses of water user associations, a distinction is often made between 'management transfer' and transfer of property rights ${ }^{1}$. Within the ideological framework from which water user associations originate, the transfer of property rights is seen as a way to create stronger private incentives for investment in common pool resources. The management transfer is seen as a lesser form, with weaker incentives for investment and coordination amongst beneficiaries, while at the same time entrusting dysfunctional state institutions with too much ownership. Adopting this lens for a moment, we will look at relevant provisions of Orissa's Pani Panchayat law to see what form of transfer has been effected. We find that the state has opted not to interfere with 'internal' disputes of the user groups as far as possible, and it has delegated considerable degree of operational control over irrigation infrastructure and irrigation water. However, on the other hand, it has retained powers to closely monitor the activities of the user groups and it can revoke the transfer of operational control through the mechanism of 'competent authorities'.

\section{Powers and functions of Farmers Organisations}

In Orissa the relationship between water user associations and the Water Resources Department takes the form of a contract. The Pani Panchayats, also known in the legislation as "Farmers Organisations", enter into an agreement in a prescribed form with the Irrigation Officer.

Section 16 of the Pani Panchayat Act, 2002 provides that objects of a Farmers Organisation is to: "promote and secure distribution of water among its users, adequate maintenance of the irrigation system, efficient and economical utilisation of water to optimise agricultural production, to protect the environment, and to ensure ecological balance by involving the farmers, inculcating a sense of ownership of the irrigation system in accordance with the water budget and operational plan." Towards these objects, Section 17 of the Pani Panchayats Act vests Farmers' Organisations with functions that include:

1 Groenfeldt, D., "Transferring Irrigation Systems from the State to Users: Questions of Management, Authority and Ownership", Paper presented at the 96th annual meetings of the American Anthropological Association, Washington DC, 1997. 
- Preparing a maintenance plan for the irrigation system in the area of its operation at the end of each cropping season and carrying out maintenance works of both the distributary system and minor, sub-minor and field drains in the area of its operation with the funds of the Pani Panchayat.

- Managing the List Irrigation points as may be handed over to the Farmers' Organisation through a mutual agreement between the two parties.

- Regulating the use of water among the various pipe outlets in its area of operation according to the warabandi schedule of the system.

- Preparing a suitable cropping programme.

- Assisting the Revenue Department in the water rates (or Water Tax).

- Collecting fees from water users of the Lift Irrigation points for payment of energy charges, repair, maintenance of machinery and distribution system and for future replacement of machines.

- Resolving disputes between members and water users of its area.

Section 20 of the Act provides that the Farmers' Organisations Panchayats may "for carrying out the performance of this Act, achieving the objects of the organisation and performing its function, levy and collect such fees as may be prescribed by Government and/ or decided by the organisation from time to time." In the case of Lift Irrigation points ${ }^{2}$ the Farmers' Organisation can fix a water rate that covers the cost of energy charges and maintenance charges of the project. The Farmers' Organisation can also levy a minimum charge that water users have to pay if they do not consume any water in a particular season.

The Act provides that the Orissa Lift Irrigation Corporation will not collect water tax from the members of a Farmers' Organisation, but the Farmers' Organisation may collect water tax in such the projects and in the manner prescribed by the Government from time to time.

Rule 7 of the Pani Panchayat Rules, $2003^{3}$ sets out rights of the Farmers' Organisation, which include rights to receive water in bulk from the Irrigation Projects for distribution among the water users on agreed terms of equity and social justice. It can levy a separate fee for maintenance of the system as well as any other fees or service charges to meet management costs and any other expenses.

Through these provisions there is a clear transfer of operation, maintenance and management responsibilities to the Pani Panchayats. The association taking over these operation, maintenance and management responsibilities is meant to be self-sustaining, supported by user cost payments from its beneficiaries and members. Significantly, the association also regulates the use of water, which is

2 "Lift Irrigation" points require energy to lift water from the main water channel, as opposed to "flow irrigation" where the water flows along the natural gradient of the land when the gates between the water channel and subsidiary channel are opened.

${ }^{3}$ Vide Notification No 14161-Irr-WB (FOT)-16/2003 of the Govt of Orissa. 
otherwise the property of the state. Presumably, the right to receive water in one's fields is conditional upon making payments of user fees (to the water user association) and water tax (for the state), so the association is in effect selling water to end-use consumers, both on its own behalf and on behalf of the state. The association is also supposed to assist the Revenue Department in the collection of water tax, making it an owner of some rights and an agent of the state in other respects.

The Farmers' Organisation is not expected to fund capital investments in irrigation infrastructure entirely by itself, but it is encouraged to formulate the project and contribute in the investment. A government scheme ${ }^{4}$ provides that for Minor or Lift Irrigation Projects, or for capital investment to renovate existing projects, the Farmers' Organisation can make an application to the District Collector. If the project proposal presented by the Farmers' Organisation is approved, the state bears 80 percent of the capital cost, with a corresponding 20 percent contribution from the Farmers' Organisation itself ${ }^{5}$. For new works funded through this contributory model Farmers' Organisation can collect user fees while the state does not levy its water tax. This suggests that in return for their investment in the irrigation infrastructure, the Farmers' Organisation are given more rights in the water that comes through the infrastructure so created. In principle, this also means that a Farmers' Organisation can raise a bank loan to fund their investments in new works, to be repaid through project revenues, i.e., the user fees collected from beneficiaries of the project. For its own share of the capital cost, the state government makes a funding proposal to NABARD, other national government programmes or donor agencies, which is eventually to be repaid by the state. However, as far as the irrigation project itself is concerned, the state's contribution is a government subsidy as it is not meant to be recovered through project revenues. The state government also has a continuing role in approving and actually implementing the construction of new irrigation infrastructure.

\section{Pani Panchayat structure and the role of the state}

A closer examination of the structure of the Pani Panchayat system reveals a multi-tiered system, with user-stakeholders represented at several levels. There appears to be a role for government at every level and in every user group entity, where the government retains the right to nominate non-voting members from its departments. These non-voting members can presumably provide both capacity building support (since the departments have longer experience with managing the irrigation system) and supervision, but their roles and purpose have not been clearly defined.

\footnotetext{
${ }^{4}$ Notification MI-MISC-15/2001 11003 /WR dated 22.03.2002, Department of Water Resources, Government of Orissa.

${ }^{5}$ For tribal sub-plan areas and the poorest districts (KBK) the state's capital contribution can be raised to 90 percent of the total capital cost of new works. Notification MI-MISC-15/2001 11003 MR dated 22.03.2002, Department of Water Resources, Government of Orissa.
} 
The general body of the Farmers' Organisation is divided into more than one "chak" . For each chak there is a Chak Committee consisting of one member each from the upper reach, middle reach and lower reach of the chak ${ }^{7}$. Each Chak also elects one of its Committee members to the Executive Committee of the Pani Panchayat. The Executive Committee of the Pani Panchayat exercises the powers and performs the functions of the Pani Panchayat. This Executive Committee may have non-voting permanent invitees nominated by the government from the Department of Water Resources and the Department of Agriculture.

For major irrigation systems, the government may declare a Distributary Area comprising more than one Pani Panchayat. The Executive Committee of each Pani Panchayat is represented in the General Body of the Distributary Committee. This general body elects an Executive Committee of the Distributary Committee. The government may also nominate non-voting members from the Water Resources, Agriculture and Revenue Departments to both the Distributary Committee and the Executive Committee of the Distributary Committee.

The government can also declare a Project Committee for an irrigation system. If distributary areas are delineated within the project area, the Executive Committee of the Distributary Committees are represented on the Project Committees. For other project areas, the presidents of all the Pani Panchayats of the project area form the General Body of the Project Committee. The Project Committee elects its Executive Committee, and in addition, the government may nominate non-voting members to the Project Committee. The General Body of the Project Committee elects an Executive Committee of the Project Committee. The government may also constitute a state level committee which has government nominees and representatives from the Project Committees.

While the powers of these non-voting government nominees have not been specified, from the fact that the state can nominate non-voting members to every institution in the Pani Panchayat system it is clear that the state continues to retain the power to supervise the functioning of the entire system. Individual Farmers' Organisations may comprise of only a part of an irrigation system, so these organisations would have to work in close coordination with higher level institutions and state agencies.

The state has a continuing role in the actual delineation the boundaries of Farmer's Organisations and other bodies in the Pani Panchayat system, and in monitoring the activities and records of Farmers' Organisations ${ }^{8}$. The government also has powers to appoint officials to exercise powers of the Farmers' Organisation and the Executive Committee till these bodies are constituted or reconstituted. ${ }^{9}$ Most importantly, the government has powers to appoint

${ }^{6} \mathrm{~A}$ "chak" is an area irrigated by one outlet.

7 Sections 3 to 9 of the Pani Panchayat Act deal with the multi-tiered structure of the Pani Panchayat system.

${ }^{8}$ Sections 3-9, 13, 28, 29.

${ }^{9}$ Section 34. 
"competent authorities" in respect of Farmers' Organisations, "to perform such duties as may be prescribed" ${ }^{\prime 10}$ in administrative order. This power of the state seems quite unconditional, except what limits would be imposed on it by principles of administrative law. This means that the department could still revoke powers transferred to Pani Panchayats under the Act, which makes the transfer of power less complete than it would seem at first glance.

\section{Dispute Resolution}

However, in contrast to the extensive administrative powers that the state continues to hold, the power of dispute resolution has been delegated to the user groups themselves. Any dispute or difference "touching the constitution, management, powers or functions" of a Farmers' Organisation arising between the members is to be settled by the Executive Committee of the Farmers Organisation. This can then be escalated up tiers of the Pani Panchayat system, to the Executive Committee of the Distributary Committee, the Executive Committee of the Project Committee, and finally to the State Level Committee whose decision shall be final ${ }^{11}$. Farmer's Organisations also have the power to compound offences punishable under the Act by imposing a penalty on the person accused of committing the offence ${ }^{12}$.

\subsection{Administrative reform: policy and practice around water user associations}

Water user associations were brought into Orissa under the World Bank assisted Orissa Water Resources Consolidated Project which was initiated in 1996. These early water user associations were registered societies, formed on a somewhat ad hoc basis and they were given limited operation and maintenance responsibilities over local irrigation systems. The registered societies did not have formal rules of elections and decision-making, but were instead expected to be driven by the consensus of its members. These water user associations attracted much criticism, and journalistic accounts of the time suggested that there was little to show on the ground, even for water user associations that were being cited as case studies of success ${ }^{13}$. However, confusingly, official documents of the state government and the multilateral agencies declared the same experiment to be successful enough to be considered a basis for more formal and legally mandated Pani Panchayats to be set up across the state ${ }^{14}$. Subsequently, the state

\footnotetext{
${ }^{10}$ Section 21.

${ }^{11}$ Section 26.

12 Section 25.

${ }^{13}$ Sainath, P. "Little pani, less panchayat", The Hindu, Sept 152002 and Sept 222002 (2-part article).

${ }^{14}$ See Implementation Completion Report (IDA-28010) on a credit in the amount of US\$ 290.9 Million to the Government of India for Orissa Water Resources Consolidation Project, World Bank Report No 31323, 2005, available at www.worldbank.org; Secretariat Establishment Manual-1, Department of Water Resources, Govt of Orissa, undated.
} 
government has continued to support its Pani Panchayat initiative, and to build on it with new schemes and incentives.

Policy makers of the time could not have been unaware of the dissonance between independent reports and official statements. Within official circles in the state government, there is an (unpublished) view that the early criticism was best dismissed as teething problems of institutions that were not fully developed. It was assumed that enacting a law for Pani Panchayats with formal elections and more extensive roles and responsibilities would strengthen the Pani Panchayats and help them overcome problems of lack of accountability and participation. However, interestingly, the state chose not to prescribe too many formal rules of decision-making such as notice before meetings, quorums for meetings, simple majorities and two-thirds majorities for decisions that are put to vote. Instead, it opted for a community-centric approach, expecting farmers of an irrigation reach to make consensus based decisions.

Yet it is difficult to build a conspiracy theory based on the state government's disregard for early criticism of the water user associations because there is no apparent divestment of public assets to the usual suspects, the multinational companies or local business interests. The reasons behind its going ahead and consolidating its early initiative are perhaps more complicated.

Through the years when the water user associations were introduced and then mainstreamed, the state was under steady pressure to reduce its fiscal deficit by curtailing its expenditure ${ }^{15}$. Reducing the size of its Irrigation Department by laying off its field staff, and divesting the operation and maintenance responsibilities of this department to self-sustaining user groups is step towards reducing its expenditures, even though it would only constitute a small portion of the state's overall spending. The World Bank's Pani Panchayat initiative and reformulation of the Irrigation Department into the Department of Water Resources were both part and parcel of the World Bank's US\$ 290.9 million lending for the Orissa Water Resources Consolidation Project of 1996 - in the rationale of multilateral lending these 'sector reform' aspects of the programme would have been thought of as ways to make the core investments more effective. Perhaps the state government at the time either shared the World Bank's view on necessary sector reforms, or it agreed to swallow the conditionality as a part of the overall lending strategy. The state government's continued support for Pani Panchayats does suggest that decision-makers in the state believe the initiative is positive and should be taken forward. Perhaps this also means that the initiative has vote-winning potential, as after all turning off the tap on the direct operations and maintenance spending of the department is balanced off by decentralisation of funds and power to the Pani Panchayats.

${ }^{15}$ See International Bank for Reconstruction and Development and the International Development Association Program Document for a Proposed Loan in the Amount of US\$85 Million and a Proposed Credit in the Amount of SDR 27.4 Million (US\$40 Million equivalent) to India for the Orissa Socio-Economic Development Program, Report No 26550-IN, The World Bank, available at www.worldbank.org 
What is more problematic about this initiative is that while the model itself is inspired by instances of volunteerism and social action - Pani Panchayats are expected to come together on their own, register themselves with the state and formulate their own proposals that they can present to the state for funding - there is very little audit to show that the state has been able to encourage healthy forms of volunteerism or social action. There have been a few awareness generating programmes of the state government, but by and large the state has little ability or interest for supporting community initiatives with capacity building programmes. The lack of systematic audit means that future action is not based on an evaluation of successes and failures. Significantly, it also means that the decisionmaking process does not have to be substantiated, and it cannot in fact be subjected to any meaningful or systematic scrutiny either within the state or outside.

\subsection{Politics of water user associations}

To make sense of the continued interest in water user associations it is useful to look at where the associations fit into the local agrarian and social structure. This is not to say that the form and specifics of Orissa's water user association policies is somehow unique to a particular agrarian and political structure. In fact, the water user association model of governance reform is quite obviously driven by a 'one size fits all' mindset as the policy is quite similar to what has been implemented elsewhere in the world and across many states of India. However, a policy that was merely imitative of what had been tried out elsewhere in the world would not usually have been sustained and strengthened by a politically astute government unless there were also some local reasons for support.

To get a sense of these local reasons of support, the dynamics of agrarian structure, caste, class and poverty in Orissa are looked at. The water user groups of Orissa are embedded in the agrarian structure of what has been widely classified as one of the most agriculturally backward states of India. Agriculture's share of Orissa SDP has declined rapidly since Independence, from 67 per cent in 1951-52 to 31 per cent in 1999-2000 ${ }^{16}$. Agricultural activity is, however, still critical to the majority of Orissa's population where, according to the 2001 census, agriculture alone provides direct and indirect employment to around 65 per cent of the total workforce of the state ${ }^{17}$.

In the pattern of landholdings in Orissa there are an overwhelming number of small and marginal farmers. A recent agricultural census puts the total number of operational holdings at 3.97 million, with small and marginal farmers (i.e., farmers who cultivate less than two hectares of land) hold 84 per cent of the total. However, this 84 percent of operational holdings of small and marginal farmers constitutes only 52 per cent of the total operational area, which implies that nearly half of all the agricultural land is held by only 16 per cent of landholders. The highest level of disaggregation available in the data is that the largest farmers

\footnotetext{
${ }^{16}$ Orissa State Development Report 2001, Planning Commission: New Delhi, 2003.

17 Ibid.
} 
(who hold more than 4 hectares of land) constitute only 4 per cent of total holdings but occupy a substantial 20 per cent of the total operated area. The picture is further complicated by the fact that a large proportion of Orissa's farmers lack the infrastructure required to make productive use of their land ${ }^{18}$. When put together, this data suggests that a small number of large farmers, who are presumably the elite of the farming community co-exist with a large number of small and marginal farmers.

This picture of a small number of elites in a farming community that consists mainly of small and marginal farmers corresponds with other social and spatial aspects of poverty in Orissa. The Orissa State Development Report observes that Orissa has high levels of social inequality ${ }^{19}$. The state has a sizeable proportion of SC/ ST population at 38.41 percent, of which 16.20 percent are scheduled castes and 22.21 percent are scheduled tribes, in comparison with a national average of 16.48 percent scheduled castes and 8.08 percent scheduled tribes. The Report also notes that the process of socio-economic transformation in Orissa has been much slower than in other states of the country ${ }^{20}$. While there have been improvements in the level of rural infrastructure available in the state, according to the Report the politics of "soft governance" by the state to render patronage to the privileged section of society has meant that investments in rural social and economic infrastructure have failed to reach the real target groups ${ }^{21}$.

Recent research also points to very significant regional differences in the incidence of poverty within Orissa, with considerably higher levels of poverty in the southern and north-western regions as compared to the coastal plains (See table $1)^{22}$. These regional differences also correspond with differences in the degree of economic deprivation of different ethnic groups and their spatial concentration. The incidence of poverty among SC and ST population in the southern and northern region is very high, and significantly it is in these regions that 88.56 per cent of the state's ST population and 46.23 per cent of the state's SC population reside.

Table 1: Region-wise and Social Group-wise Incidence of Poverty, Rural Orissa, 1999-2000 ${ }^{23}$

\footnotetext{
18 Ibid.

19 Ibid.

20 Ibid.

21 Ibid.

22 Orissa Human Development Report 2004, Planning and Coordination Department, Govt of Orissa: Bhubaneshwar, 2005

23 Estimates of poverty ratio from Arjan de Haan and Amaresh Dubey, "Poverty in Orissa: Divergent Trends? With Some Thoughts on Measurement Issues", mimeo, paper presented at the Workshop on 'Monitoring of Poverty in Orissa', 26-27 February 2003, Bhubaneswar, Cf. Ibid.
} 


\begin{tabular}{|l|r|r|r|r|}
\hline \multicolumn{1}{|c|}{ Region $^{24}$} & \multicolumn{4}{c|}{ Social Groups } \\
& \multicolumn{1}{|c|}{ SC } & \multicolumn{1}{c|}{ ST } & \multicolumn{1}{c|}{ Others } & \multicolumn{1}{c|}{ All } \\
\hline Coastal & 63.63 & 42.18 & 24.32 & 31.74 \\
\hline Southern & 92.42 & 88.90 & 77.65 & 87.05 \\
\hline Northern & 61.69 & 57.22 & 34.67 & 49.81 \\
\hline Orissa & 73.08 & 52.30 & 33.29 & 48.01 \\
\hline
\end{tabular}

In this setting, when researching the state's agricultural economy and land distribution pattern, the authors of the State Development Report have a telling narrative of the situation in a few villages located in Southern and Nothern regions of Orissa:

\begin{abstract}
"In this village [Haradtal] there exists one watershed to provide irrigation facility to around 100 acres of land during Kharif season and to around 50 acres of land during Rabi season. However, from our discussion held with the poor Dalit people of the village, it was revealed that the watershed of the village, in fact, served the interest of the Gauntia (village headman) family mainly. Similarly, in village Dhumamara a new pond to develop a watershed for the people of the locality was being dug up in pre-monsoon season under the food for work programme during April-June 2001. The Dalit Christian households of the village reported that after the completion of the pond it would provide irrigation benefit to the land of one gauntia family of Lurkipali. This family owns around 50 acres of land down below the watershed. The villagers had raised objection with the DRDA/ Block Office when this site was selected. However, it was of no avail. With a plea of lack of adequate land in the site chosen by the villagers, the officials decided to locate the project in the present site. (...) In Lumti village one lift irrigation point set up at the bank of river Safai presently serves the interest of one influential priestly Brahmin family of the village. Out of 60 acres of land covered under irrigation, this family alone owns 50 acres of land in the command area of the irrigation point. Apart from that in the so called irrigated village Jarmal it was found that according to revenue record out of 674.48 acres of cultivable land in the village, 234.33 (34.74\%) acres were classified as irrigated. However, our enquiry made with the villagers revealed that hardly 50 acres of land in that village was enjoying the benefit of double crops in a year." 25
\end{abstract}

This anecdotal information only seems to confirm the inequality of power and privilege that the data suggests. In this setting, it is easy to subvert the Pani Panchayat system into an instrument of patronage for the privileged few, whose economic power can then be further reinforced by their priority access to state resources and patronage. The seemingly democratic system for appointment of Pani Panchayat committees and office bearers, with rules for geographical representation and formal elections seem to have not made any radical difference to the pattern of power distribution.

${ }^{24}$ The regions have been classified as: (i) Coastal region consisting of Balasore, Cuttack, Ganjam and Puri districts; (ii) Northern region consisting of Dhenkanal, Keonjhar, Mayurbhanj, Sambalpur, and Sundargarh districts; and (iii) Southern region consisting of Balangir, Kalahandi, Kandhamal, and Koraput districts.

${ }^{25}$ Supra n. 11. 
If small farmers do not come together to exercise collective power and use the system of the Pani Panchayats to their advantage, this is partly a problem of social organisation and the state of politics, but given the social setting, the law itself is based on principles that reinforce inherent social inequalities. While the Pani Panchayat system can help channel large amounts of state investment in expansion or repair of irrigation infrastructure, there are few safeguards in the system such as tariff guidelines that can protect the interests of the poorest. This actually means that the lands of marginal farmers (who cannot afford to make a contribution towards operating expenses) would actually not get any of the benefits of the state's capital spending in irrigation infrastructure either. On the other hand, a small number of elites in the agrarian structure can, if they make their share of financial and managerial effort, stand to benefit disproportionately from state subsidies. At the same time, this group could also use the Pani Panchayat law to acquire more direct management control over irrigation infrastructure than they would have had under conventional departmental systems, further consolidating their power in the system.

\section{Conclusion}

Orissa's Pani Panchayat law does not result in a full privatisation of the state's irrigation infrastructure, but it does outsource responsibility for operations and maintenance user groups who are expected to finance their activities through fees collected from users. These user groups act as agents of the state in some of their responsibilities, but more importantly, as far as their main responsibilities are concerned they act on their own behalf. In this respect should they be treated as a form of local government, or as a form of privatisation? This is a question that is never entirely clear for user groups - as in the case of the Farmers' Organisations, they may sign a contract with the main department, but they draw legitimacy from the fact that they are elected from user-citizens. In comparison, a private contractor selected through a public procurement process would have a far more contract-driven relationship with the state.

In a regular privatisation framework, the powers and continuing responsibilities of the state vis-à-vis the contractor and beneficiaries would have to be more clearly defined. Under the present law, the state continues to have a presence, and it can choose to extent its role, but the grounds on which beneficiaries or other aggrieved parties can demand that the state exercise its powers is not laid down anywhere. This loosely defined structure compromises accountability of both department and user group, making the structure imperfect from the perspective of property rights as it results in economic incentives that are not clearly defined. The problems of lack of accountability and transparency also become more serious when we look to the social and economic setting in which it the law is implemented, for the nebulous structure of the system makes it difficult to make rights based demands at the level of local implementation.

The lack of audit and performance monitoring of the Pani Panchayat system creates an information vacuum that makes it difficult to scrutinise or discuss the state's decision making process. Where there are undeniable deep rooted differences and inequalities, the law is also inadequate in that it has no 
safeguards to protect the interests of its weaker beneficiaries. The law takes no account of the special subsistence needs of small and marginal farmers. It is free to set its tariff levels, without anything akin to a base tariff level for a specified amount of basic consumption. At the same time, the law can also help reinforce existing forms of inequality and exclusion by legitimising privileged access to state subsidies for local elites in the community.

Yet neither a complete privatisation nor a return to full departmental control is desirable or feasible. Given the problems of Orissa's social and economic setting a state-run system is as open to abuse, we are told was the case before the Pani Panchayat reform was introduced. At the same time, given the setting a full privatisation is simply out of the question. This leaves us with few clear policy alternatives, which perhaps was the starting point for hybrid development initiatives like user groups in the first place. A focus on the detail of the policy initiative, as I have attempted in this paper, is a response to what I perceive is a lack of policy alternatives. This level of discussion keeps us within the framework of the existing law, but it helps us target the lack of accountability and audit in the framework as well as specific local manifestation of the problems of bias and exclusion.

\section{References}

de Haan, A and A. Dubey, "Poverty, Disparities, or the Development of Underdevelopment in Orissa, Economic and Political Weekly, 28 May 2005.

Groenfeldt, D., "Transferring Irrigation Systems from the State to Users: Questions of Management, Authority and Ownership", Paper presented at the 96th annual meetings of the American Anthropological Association, Washington DC, 1997.

Mohanty, M., "Class, caste and dominance in a backward state: Orissa", in F. Frankel \& M.S.A. Rao, Dominance and state power in modern India: Decline of a social order, New Delhi: Oxford University Press, 1990.

Sainath, P. "Little pani, less panchayat", The Hindu, Sept 152002 and Sept 22 2002 (2-part article).

Orissa Human Development Report 2004, Planning and Coordination Department, Govt of Orissa: Bhubaneshwar, 2005

Orissa State Development Report 2001, Planning Commission: New Delhi, 2003.

International Bank for Reconstruction and Development and the International Development Association Program Document for a Proposed Loan in the Amount of US\$85 Million and a Proposed Credit in the Amount of SDR 27.4 Million (US\$40 Million equivalent) to India for the Orissa Socio-Economic Development Program, Report No 26550-IN, The World Bank, available at www.worldbank.org

Implementation Completion Report (IDA-28010) on a credit in the amount of US\$ 290.9 Million to the Government of India for Orissa Water Resources Consolidation Project, World Bank Report No 31323, 2005, available at www.worldbank.org 
Secretariat Establishment Manual-1, Department of Water Resources, Govt of Orissa, undated 